\title{
Influence of pH on Water Hyacinth Ponds Treating and Recycling Wastewater
}

\author{
Sèna Peace Hounkpe¹, Martin Crapper², Albant Sagbo ${ }^{3}$, Edmond Adjovi', Martin Pépin Aina ${ }^{3}$ \\ ${ }^{1}$ Ecole Nationale Supérieure des Travaux Publics, Université des Sciences Technologies, Ingénierie et Mathématiques d’Abomey, \\ Abomey, Benin \\ ${ }^{2}$ Institute of Infrastructure and Environment, School of Engineering, University of Edinburgh, Edinburgh, UK \\ ${ }^{3}$ Institut National de l'Eau, Université d'Abomey-Calavi, Abomey-Calavi, Benin \\ Email: senapeace@yahoo.fr
}

How to cite this paper: Hounkpe, S.P. Crapper, M., Sagbo, A., Adjovi, E. and Aina, M.P. (2022) Influence of $\mathrm{pH}$ on Water Hyacinth Ponds Treating and Recycling Wastewater. Journal of Water Resource and Protection, 14, 86-99.

https://doi.org/10.4236/jwarp.2022.142006

Received: November 16, 2021

Accepted: February 12, 2022

Published: February 15, 2022

Copyright $\odot 2022$ by author(s) and Scientific Research Publishing Inc. This work is licensed under the Creative Commons Attribution International License (CC BY 4.0).

http://creativecommons.org/licenses/by/4.0/

\begin{abstract}
This work has examined the effects of $\mathrm{pH}$ on the treatment efficiency and biomass production rate of water hyacinth ponds (WHP) treating domestic wastewater. Experiments were carried out outdoor in WHP, working under batch and subtropical environmental conditions, using pre-treated sewage with $\mathrm{pH}$ varying from 5 to 9 . It was observed that the plants regulated the $\mathrm{pH}$ of the medium to within 6.4 to 7.1 during the treatment processes independently of influent wastewater $\mathrm{pH}$ ranges. This adjustment reduced the treatment performances and the biomass production in ponds, the alkaline conditions in ponds being less favorable to the activities of the plants. The optimal removal and biomass production was achieved with influent $\mathrm{pH}$ of 7 lying in the above interval. So the optimum influent $\mathrm{pH}$ for the growth of plants and the removal of nutrients and organic matters in WHP is within $\mathrm{pH} 6.4$ to $\mathrm{pH} 7.1$.
\end{abstract}

\section{Keywords}

Sewage, Treatment, Biomass Production, Water Hyacinth, $\mathrm{pH}$

\section{Introduction}

Water hyacinth (WH), Eichhornia crassipes (Martius) Solms-Laubach, is an erect, stoloniferous, free-floating, perennial and vascular aquatic weed with elongated petioles ( $5 \mathrm{~cm}$ of diameter; 30 to $50 \mathrm{~cm}$ of length, but can reach up to $1.5 \mathrm{~m}$ ) [1] [2]. In the absence of its original suite of natural, enemies, and usually in nutrient-enriched waters, E. crassipes populations increase rapidly, doubling under suitable conditions every 6 to 18 days [3]. Due to their vigorous productivity and their ability to reproduce successfully in new nutrient-enriched habitats make 
WH a good candidate for wastewater purification and nutrient recycling [4] [5] [6] [7]. Water hyacinth ponds (WHP) have been proved to be efficient in improving effluent quality from oxidation ponds and as a main component of an integrated advanced system for treatment of municipal, agricultural and industrial wastewaters [5] [6] [8] [9]. However, as for all biochemical processes, the potential of hydrogen $(\mathrm{pH})$ could be a limiting factor to this ability of WH to treat wastewater and produce biomass [10].

$\mathrm{pH}$ is an important environmental parameter in wastewater treatment. Water $\mathrm{pH}$ affects many biochemical processes involved in macrophyte growth and metabolism, including the bioavailability of carbon dioxide for photosynthesis and the availability and absorption of nutrient ions. The $\mathrm{pH}$ can affect the availability of essential minerals (phosphate, iron, molybdenum, zinc, manganese) or the solubility of toxic substances [10]. Low $\mathrm{pH}$ increases the risk of the presence of metals (copper, for example) in a more toxic ion form. High $\mathrm{pH}$ increases the concentrations of toxic ammonia [11] [12].

$\mathrm{WH}$ is reported to tolerate $\mathrm{pH}$ ranging between 4 and 10 . However, several studies have shown that $\mathrm{pH}$ can significantly inhibit WH growth, as for several aquatic plants [1] [2] [13] [14]. Similarly, Azov and Goldman [15] have reported that high $\mathrm{pH}$ level is detrimental to $\mathrm{WH}$ growth due to deficiencies in nitrogen stripping [15].

However, the direct influence of $\mathrm{pH}$ on the wastewater purification performance of WH has not been investigated. Most research works on the effect of $\mathrm{pH}$ on WH have focused mainly on the determination of the limit $\mathrm{pH}$ after which plants cannot growth.

The present research focused on determining the relationship between $\mathrm{pH}$ and the performance of WHP for domestic wastewater treatment and nutrient recycling. The objectives of present research are to study the effects of acidic, neutral and basic ranges of $\mathrm{pH}$ on WH biomass production and performance in WHP for wastewater treatment in a batch flow condition in order to determine the optimum range of $\mathrm{pH}$ for efficient treatment and biomass production.

\section{Materials and Methods}

The study is conducted on the University Campus of Abomey-Calavi, located in Abomey-Calavi, a city of southern Benin. Benin is a tropical country of West Africa, located near the equator and between the parallels $6^{\circ} 30^{\prime}$ and $12^{\circ} 30^{\prime}$ of latitude and $1^{\circ}$ and $3^{\circ} 40^{\prime}$ of longitude. The average temperature varied between $23^{\circ} \mathrm{C}$ and $32^{\circ} \mathrm{C}$ with an annual average sunshine period of 2290 hours, an average annual rainfall recorded of $1308 \mathrm{~mm}$ and an average evaporation of 7200 $\mathrm{mm}$ /day for the southern part [16] [17].

The experiment was carried out with mini-ponds consisting of plastic containers of $52.0 \mathrm{~cm}$ of length, $42.5 \mathrm{~cm}$ of width and $35.5 \mathrm{~cm}$ depth, filled with $50 \mathrm{l}$ of anaerobically treated wastewater from university halls. The characteristics of the raw wastewater and anaerobic pond effluent are shown in Table 1. 
Table 1. Raw wastewater and anaerobic pond effluent.

\begin{tabular}{ccccc}
\hline Parameters & Unit & Raw sewage & $\begin{array}{c}\text { Anaerobic pond } \\
\text { Effluent }\end{array}$ & $\begin{array}{c}\text { Removal } \\
\text { rate } \%\end{array}$ \\
\hline Temperature & ${ }^{\circ} \mathrm{C}$ & $26.8 \pm 0.1$ & $28.3 \pm 0.1$ & \\
$\mathrm{pH}$ & & $6.47 \pm 0.01$ & $6.773 \pm 0.001$ & \\
$\mathrm{e}_{\mathrm{H}}$ & & $24.1 \pm 0.8$ & $6.5 \pm 0.1$ & \\
$\mathrm{r}_{\mathrm{H}}$ & & $13.75 \pm 0.05$ & $13.16 \pm 0.03$ & \\
$\chi$ & $\mu \mathrm{S} / \mathrm{cm}$ & $745 \pm 5$ & $108 \pm 2$ & \\
Turbidity & $\mathrm{NTU}$ & $150.7 \pm 1.5$ & $72.5 \pm 1.3$ & $52 \%$ \\
$\mathrm{COD}$ & $\mathrm{mg} / \mathrm{l}$ & $516.9 \pm 25$ & $175.4 \pm 7.0$ & $66 \%$ \\
$\mathrm{BOD}_{5}$ & $\mathrm{mg} / \mathrm{l}$ & $218 \pm 35$ & $101 \pm 2$ & $54 \%$ \\
$\mathrm{MES}$ & $\mathrm{mg} / \mathrm{l}$ & $160 \pm 2$ & $75 \pm 0.5$ & $53 \%$ \\
$\mathrm{NTK}$ & $\mathrm{mg} / \mathrm{l}$ & $20.86 \pm 0.50$ & $15.7 \pm 0.3$ & $25 \%$ \\
$\mathrm{~N} \mathrm{NO}_{3}^{-}$ & $\mathrm{mg} / \mathrm{l}$ & $1.56 \pm 0.01$ & $1.1 \pm 0.0$ & $29 \%$ \\
$\mathrm{~N}^{-N O} \mathrm{NO}_{2}^{-}$ & $\mathrm{mg} / \mathrm{l}$ & $0.00 \pm 0.00$ & $0.22 \pm 0.00$ & \\
$\mathrm{P}_{-} \mathrm{PO}_{4}^{3-}$ & $\mathrm{mg} / \mathrm{l}$ & $26.6 \pm 0.5$ & $5.55 \pm 0.10$ & $79 \%$ \\
Faecal Coliforms & $/ 100 \mathrm{ml}$ & $1.05 \mathrm{E}+05 \pm 465$ & $1.57 \mathrm{E}+04 \pm 165$ & $85 \%$ \\
\hline
\end{tabular}

Five (05) mini ponds MP (with 2 duplicate for each which made in total 15) containing anaerobically treated wastewater at different $\mathrm{pH}$ varying from 5 to 9 were used. These $\mathrm{pH}$ were chosen to comply with the $\mathrm{pH}$ range for the survival of WH [1]. The ponds occupied a total surface area of about $4 \mathrm{~m}^{2}$; the small surface covered reduced the environmental heterogeneities in the ponds. The cultures were started with six (06) WH healthy plants.

In previous studies on the effect of the $\mathrm{pH}$ on other plants species, researchers used strong acid such as $\mathrm{HNO}_{3}, \mathrm{H}_{2} \mathrm{SO}_{4}$ or $\mathrm{HCl}$ and strong acid such as $\mathrm{KOH}$ or $\mathrm{NaOH}$ to adjust the initial $\mathrm{pH}$ of the culture medium [10] [18] [19] [20]. The initial $\mathrm{pH}$ of the effluent from the anaerobic pond used in this study was 6.8 .

To obtain the desired $\mathrm{pH}$, the effluent from the anaerobic pond was spiked with sulphuric acid $\left(\mathrm{H}_{2} \mathrm{SO}_{4}\right)$ or sodium hydroxide $(\mathrm{NaOH})$ depending on the $\mathrm{pH}$ level to be achieved.

The WH clones used were collected on Lake Nokoue located in southern Benin. They were then grown for several months in a pond on the University Campus of Abomey-Calavi. Healthy plants of similar size, shape and height were washed several times using tap water. Six of these plants were chosen and were introduced directly into the experimental pond without further acclimatisation. The behaviour of the plants depends on their immediate previous history [21]. To avoid systematic errors related to the use of populations of different histories, the experiments for each study were carried out simultaneously in parallel in different mini-ponds under the same conditions with plants from the same source. 
The total experimental period was twenty-one (21) days. The MP were operated under batch flow and natural tropical environmental conditions. The influent medium used was not replaced during the whole experimental period. The plants were left to grow in the ponds for the retention time or until complete wilting, if it occurred before the end of this experimental period.

The number of plants was counted in each MP at the beginning, the seventh, the fourteenth and the twenty-first day. Samples were taken on the same days for the measurement of total suspended solids (TSS), the chemical oxygen demand (COD), the biochemical oxygen demand measured after five-day at $20^{\circ} \mathrm{C}$ $\left(\mathrm{BOD}_{5}\right)$, the total nitrogen $(\mathrm{TN})$, orthophosphates and Total Nitrogen Kjeldahl (TNK). The environmental parameters such as temperature, turbidity and $\mathrm{pH}$ were measured on daily basis. The plant fresh weight (FW) and the faecal coliforms content of the medium were measured at the beginning and the end of the experiment. The fresh weight was measured by removing the excess water by placing and rolling the plants cautiously between absorbent paper tissues and by weighing the biomass immediately after that. Knowing the biomass weight, the plant relative growth rate (RGR) was calculated by equations below [10] [22] [23]:

$$
\mathrm{RGR}=\left[\ln \left(m_{f} / m_{i}\right)\right] / t
$$

where $m_{i}$ and $m_{f}$ are respectively the initial and the final wet weight of plants at the start and the end of the experimental period and $t$ is the number of days between two weighings.

The significance of the relation between the $\mathrm{pH}$, growth rate and removal performances of the WH was studied by means of statistical analysis using p-values by correlation matrix.

\section{Results and Discussions}

\subsection{Evolution of the Environment Parameters}

The temperature conditions in the different WHP are presented in Figure 1. The water temperature varied between $24.9^{\circ} \mathrm{C}$ and $27.3^{\circ} \mathrm{C}$ in all the ponds with an average temperature of $25.9 \pm 0.6$ throughout the experimental period.

The water temperature showed reasonably low variation and stayed within the optimum temperature range $\left(22^{\circ} \mathrm{C}\right.$ to $\left.30^{\circ} \mathrm{C}\right)$ for $\mathrm{WH}$ growth [14]. The pattern of temperature changes was almost the same in all ponds. The changes in temperature did not depend on the initial $\mathrm{pH}$ of the pond but were related to the weather conditions.

The initial turbidity of $72.5 \pm 1.3$ NTU dropped progressively from the first day to the eighth day where it reached average values of $2.5 \pm 1.3 \mathrm{NTU}$ (Figure 2 ). This was due to the rapid settling of suspended solids. From the eighth day, the turbidity value passed from an average of 3.81 NTU to 23.36 NTU in the ponds with $\mathrm{pH}$, and remained around this value till the end of the experiment. This increase in turbidity can mainly be explained by the growth of algae 


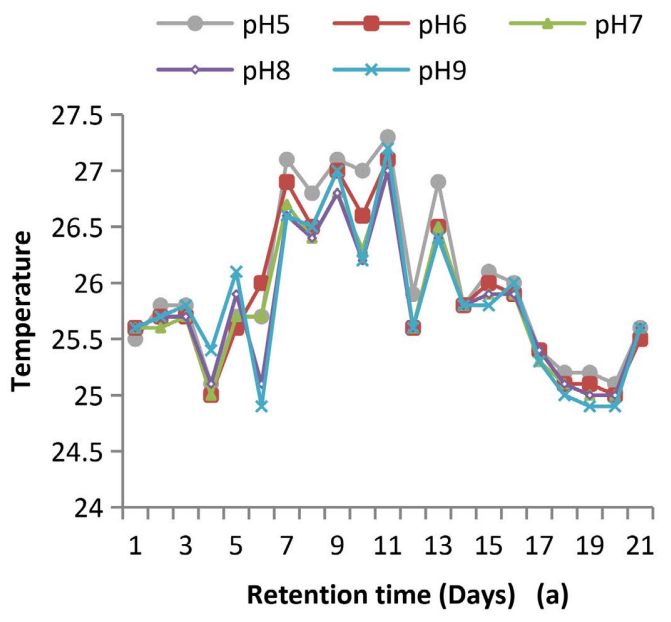

Figure 1. Evolution of temperature in ponds.

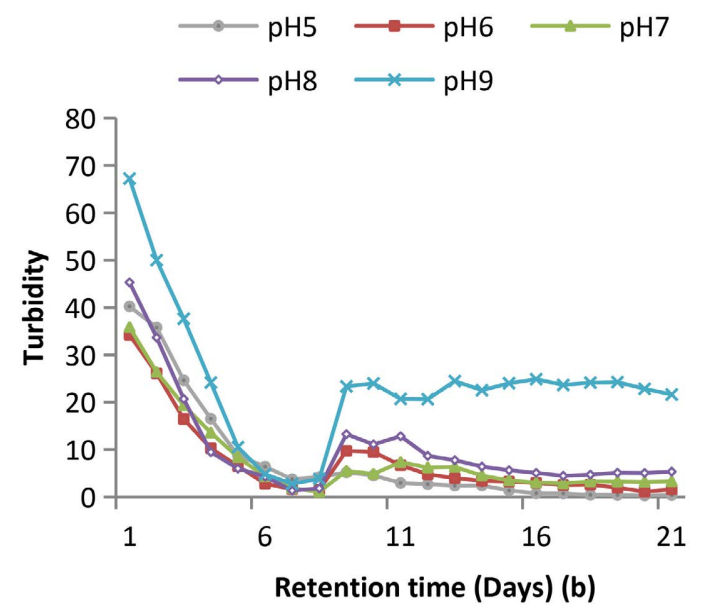

Figure 2. Evolution of the turbidity in ponds.

biomass in ponds with $\mathrm{pH} 9$, which remained in ponds till the end of experiment due to the low growth rate of WH observed.

\subsection{Evolution of the Potential of Hydrogen ( $\mathrm{pH})$}

The evolution of $\mathrm{pH}$ in ponds was highly related to the influent $\mathrm{pH}$ (Figure 3 ).

In ponds with acidic initial $\mathrm{pH}$, the daily recorded $\mathrm{pH}$ values increased rapidly the first days of the experiment. From the fifth day, the values continued increasing, but slowly, to reach an average $\mathrm{pH}$ of 6.44 in both ponds with initial $\mathrm{pH}$ of 5 and 6.

In contrast, in ponds with $\mathrm{pH} 8$ and $\mathrm{pH} 9$, the $\mathrm{pH}$ dropped, following almost the reverse trend compared to that of acidic influent water. At the end of the 21 days retention time, the average $\mathrm{pH}$ values recorded were 6.98 and 7.08 respectively in ponds with initial alkaline $\mathrm{pH} 8$ and $\mathrm{pH} 9$.

In ponds with $\mathrm{pH} 7$, a decrease in $\mathrm{pH}$ values was observed but it was not pronounced. The $\mathrm{pH}$ passed from 7 to an average value of 6.75 at the end of the experiment. 


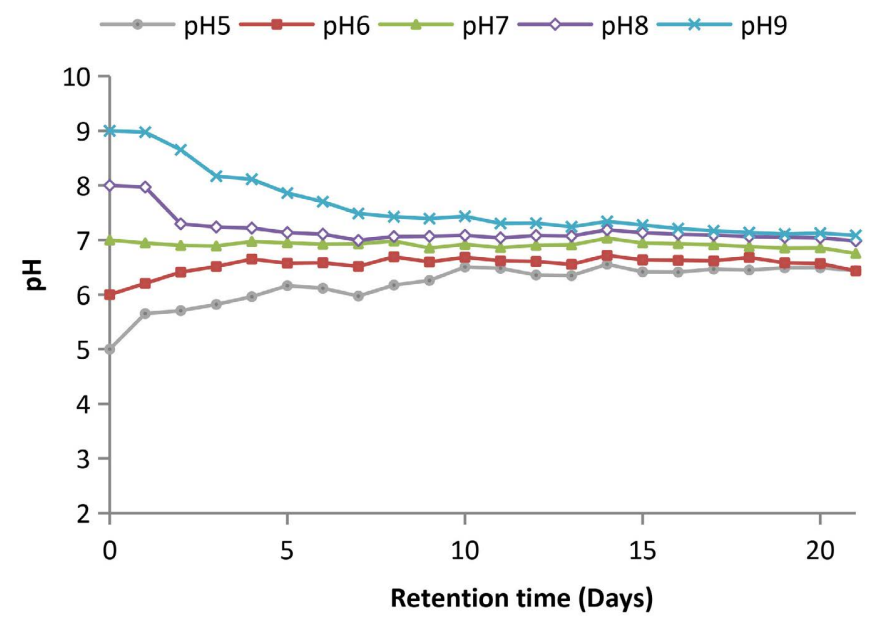

Figure 3. Evolution of $\mathrm{pH}$ in ponds.

It has been observed that all the $\mathrm{pH}$ values converged toward $\mathrm{pH}$ values in the range of 6.4 and 7.1. WH seemed to find this range of $\mathrm{pH}$ values optimal for their growth. This range is closer to optimum range for $\mathrm{WH}$ growth observed in previous studies. In fact, Balasooriya et al. [24] has reported, by studying WH growing in different water streams polluted by certain industrial effluents water, that optimum hyacinth growth occurred at $\mathrm{pH}$ within 6.0 and 7.0. Delgado et al. [25], meanwhile, found this optimum growth occurring between $\mathrm{pH}$ ranges of 6.7 to 7.3 with an experiment carried out in a greenhouse at a temperature between $28^{\circ} \mathrm{C}$ and $30^{\circ} \mathrm{C}$ using slurry containing pig manure as the nutrient source.

It has been observed here that when the influent $\mathrm{pH}$ is not within the optimal range for the plants' growth, but within the levels of $\mathrm{pH} 4$ to $\mathrm{pH} 10$ which they can tolerate for their survival as stated by Center et al. [1], WH seems to have the ability to adjust the medium $\mathrm{pH}$, whether initially acidic, neutral or alkaline, to their requirement.

This adjustment can be associated with the changes in carbon-equilibrium states [26].

It is known, the carbonate ions $\left(\mathrm{CO}_{3}^{2-}\right)$ and the bicarbonate ions $\left(\mathrm{HCO}_{3}^{-}\right)$act as the primary buffer for most natural waters. Reactions that produce or consume carbon dioxide $\left(\mathrm{CO}_{2}\right)$ may alter the $\mathrm{pH}$ temporarily until equilibrium with the atmospheric $\mathrm{CO}_{2}$ is re-established (Gilmour, 1992). The drop in $\mathrm{pH}$ under alkaline conditions could then be due to the inability of $\mathrm{WH}$ to use up all the $\mathrm{CO}_{2}$ produced during respiration. Then, the $\mathrm{CO}_{2}$ passes into the culturing medium through plant roots. On the other hand, under acidic conditions, $\mathrm{WH}$ consumed the $\mathrm{CO}_{2}$ at higher rate than it was produced by respiration. This will result in the dissociation of carbonate and bicarbonate ions by the reaction in Equation (2):

$$
\begin{aligned}
& \mathrm{CO}_{2}+2 \mathrm{H}_{2} \mathrm{O} \leftrightharpoons \mathrm{HCO}_{3}^{-}+\mathrm{OH}^{-} \\
& 2 \mathrm{HCO}_{3}^{-} \leftrightharpoons \mathrm{CO}_{3}^{2-}+\mathrm{H}_{2} \mathrm{O}+\mathrm{CO}_{2} \\
& \mathrm{CO}_{3}^{2-}+\mathrm{H}_{2} \mathrm{O} \rightleftharpoons 2 \mathrm{OH}^{-}+\mathrm{CO}_{2}
\end{aligned}
$$


Water hyacinth will fix the molecules of $\mathrm{CO}_{2}$ formed, whilst the hydroxide ions $\left(\mathrm{OH}^{-}\right)$produced are used to increase the $\mathrm{pH}$ as alkaline conditions are created in algae ponds [27] [28].

\section{3. $\mathrm{pH}$ and Treatment Performance}

According to Figure 4(a) and Figure 4(b) and the p-value analysis, COD and $\mathrm{BOD}_{5}$ removal in WHP were highly related to influent $\mathrm{pH}(\mathrm{p}<0.02)$ even though the cumulative removal rate followed almost the same trend in all ponds. The changes, with regard to initial water $\mathrm{pH}$, showed that the removal of carbon pollution from alkaline water became more and more difficult for WH with an increase in influent water alkalinity. An increase in the influent $\mathrm{pH}$ led to a decrease in carbon pollution removal performance. The same trend was observed when influent $\mathrm{pH}$ was becoming more acidic. However, WH had better performances in carbon pollution removal in acidic water than alkaline water.

In fact, with an influent $\mathrm{pH} 5$, the overall removal of COD was $30.1 \mathrm{~g} / \mathrm{m}^{2}$ while $18.3 \mathrm{~g} / \mathrm{m}^{2}$ was registered with a $\mathrm{pH}$ 9. The influent water with a neutral $\mathrm{pH}$ showed the best removal performance.

From Figure 4(a) and Figure 4(b), the carbon pollution removal was not significantly related to the retention time ( $p>0.3$ ). By looking at Figure 4(a) and Figure 4(b), with regard to the retention time, it can be observed that the major part of the organic matter was removed within the first seven days. Indeed, the average influent COD of $175.4 \mathrm{mg} / \mathrm{l}$ was reduced after seven days retention, to values ranging from $35 \mathrm{mg} / \mathrm{l}$ to $102 \mathrm{mg} / \mathrm{l}$ at a removal rates of $17 \mathrm{~g} / \mathrm{m}^{2}$ to $32 \mathrm{~g} / \mathrm{m}^{2}$.

The highest COD removal within these seven days was achieved in ponds with $\mathrm{pH} 7$ and this reduction represented $96 \%$ of the total COD removed during the experimental period. Thus, only an average of $6 \mathrm{mg} / \mathrm{l}$ of COD has been removed from the ponds with $\mathrm{pH} 7$ from the seventh to the twenty-first day bringing down the COD to $29 \mathrm{mg} / \mathrm{l}$ at the end of the period of experiment. Similarly, the best removal of BOD was achieved with ponds with $\mathrm{pH} 7$ and the major part has been removed within the first seven days. An average BOD of $20.4 \mathrm{~g} / \mathrm{m}^{2}$ was removed in these ponds within seven days with a total removal of $21.0 \mathrm{~g} / \mathrm{m}^{2}$ at the end of the 21 days of retention. The lower removal of $18.3 \mathrm{~g} / \mathrm{m}^{2}$ was observed in ponds with $\mathrm{pH} 9$ at the end of the experimental period.

The high removal observed here within the first seven days is to the fact that the major part of the organic loads are removed in WHP within seven days retention time; therefore there is no need for ponds to have longer retention, the optimal retention time for carbon pollution removal is seven days. Increasing retention time added very little to efficiency with regard to the organic load removal. It may be worthwhile to have two ponds with retention time of about seven days than to have a pond with higher retention time.

The total suspended solids (TSS) removal rate was optimum in ponds with influent $\mathrm{pH} 7$, even though the overall removal of TSS at the end the experimental period was higher in ponds with $\mathrm{pH} 8$ (Figure $4(\mathrm{c})$ ). After seven days retention, 

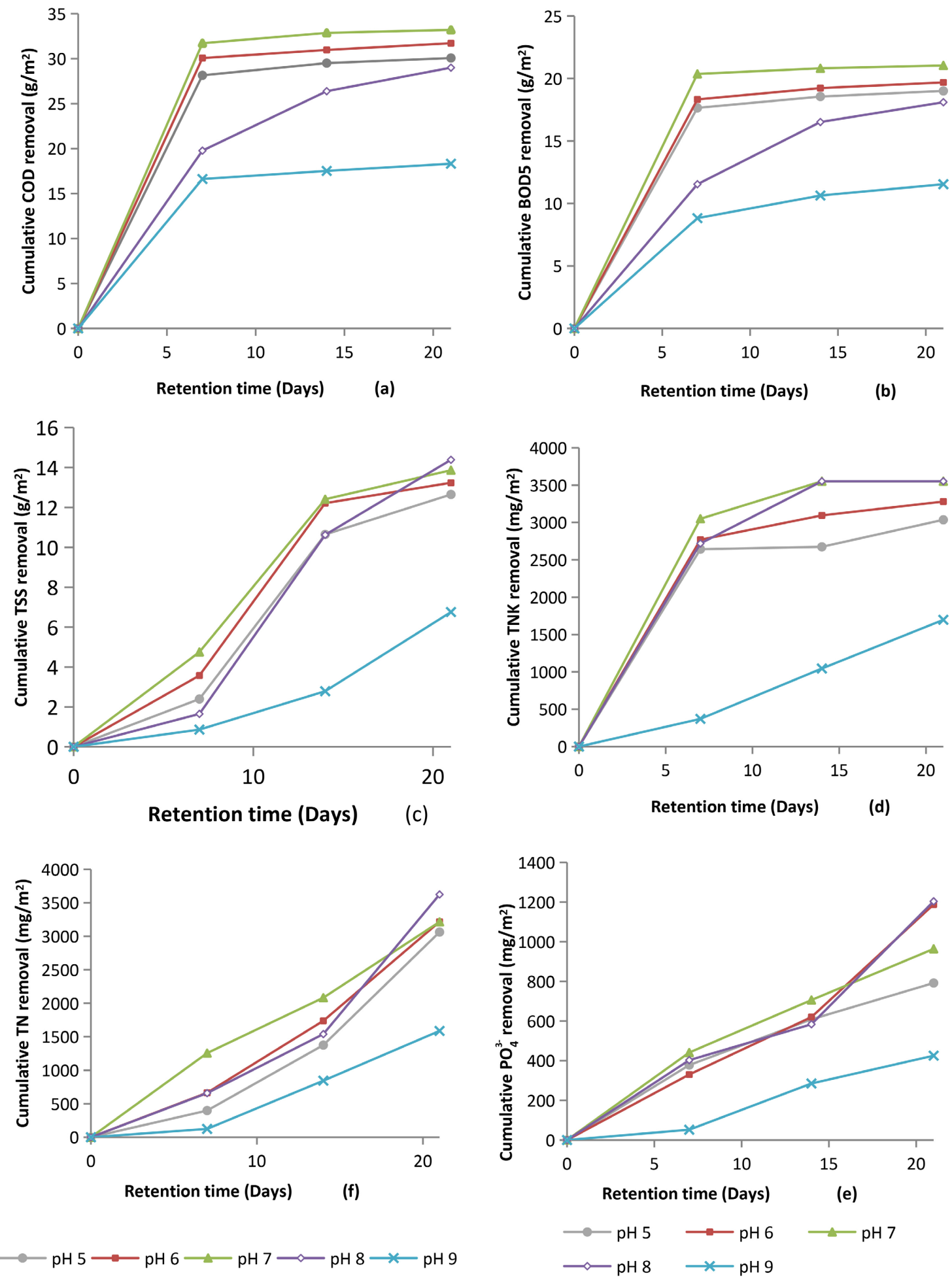

Figure 4. Performance changes of water hyacinth with influent at different $\mathrm{pH}$.

the highest reduction in TSS of $4.8 \mathrm{~g} / \mathrm{m}^{2}$ was observed in ponds with $\mathrm{pH}$ 7. This rate changed to $12.4 \mathrm{~g} / \mathrm{m}^{2}$ on the fourteenth day and then $13.9 \mathrm{~g} / \mathrm{m}^{2}$ at the end of the experiment. The highest reduction in TSS in ponds with $\mathrm{pH} 8$ was observed between the fourteenth and the twenty-first day for those ponds. 
Figure 4(d) and Figure 4(e) show the TNK and TN cumulative removal in ponds at different $\mathrm{pH}$ as function of retention time. Apart from the ponds with influent $\mathrm{pH}$ 9, the major part of TNK was removed within seven days retention time.

The maximum removal of $3050 \mathrm{mg} / \mathrm{m}^{2}$ achieved within this period was at $\mathrm{pH}$ 7 , which also had the highest overall removal of $3552 \mathrm{mg} / \mathrm{m}^{2}$ at the end of the experiment. The lowest removal rate of $1697 \mathrm{mg} / \mathrm{m}^{2}$ at the end of the experimental period was observed in ponds with influent $\mathrm{pH}$ 9. The removal of TNK seemed to not be significantly $(\mathrm{p}>0.25)$ related to the retention time (Table 2), even though the trend of the cumulative removal in ponds with $\mathrm{pH} 9$ seems to be time dependent (Figure $4(\mathrm{~d})$ ). TNK cumulative removal rate was used to measure the nitrification rate. The nitrification rate correlated with the carbon pollutant removal rate $(\mathrm{p}<0.0001)$ but the correlation with the influent $\mathrm{pH}$ seemed not very significant $(\mathrm{p}>0.058)$. The low effect of $\mathrm{pH}$ on nitrification rate may be due to the rapid adjustment of the medium $\mathrm{pH}$ by water hyacinth to values close to optimum $\mathrm{pH}$ range for nitrification, 7 to 8 [29].

Analysis of the trends of the curves of Figure 4(e) showed that the optimum TN cumulative removal was achieved in ponds with $\mathrm{pH} 7$, even though the ponds with pH 8 showed the highest overall removal of $3623 \mathrm{mg} / \mathrm{m}^{2}$ at the end of the period of the experiment. In fact, in $\mathrm{pH} 7$ the removal rate was progressive with average values of $1256 \mathrm{mg} / \mathrm{m}^{2}, 2083 \mathrm{mg} / \mathrm{m}^{2}$ and $3214 \mathrm{mg} / \mathrm{m}^{2}$, the $7^{\text {th }}, 14^{\text {th }}$, and $21^{\text {st }}$ day, respectively. In $\mathrm{pH} 8$, a sudden increase of the TN removal rate from $1539 \mathrm{mg} / \mathrm{m}^{2}$, the $14^{\text {th }}$ day to $3623 \mathrm{mg} / \mathrm{m}^{2}$ at the end of the experiment was observed. This change may be explained by the high plant growth observed in these ponds those last days after the adjustment of the $\mathrm{pH}$ in ponds. The TN removal rate was not correlated to the $\mathrm{pH}(\mathrm{p}=0.287)$ but it was significantly correlated to the retention time, the organic loads and the phosphate removal rates $(\mathrm{p}=0.001)$. The maximum $\mathrm{TN}$ removed represented $94.1 \%$, which was higher than $83.26 \%$ removal reported by [30] after 4 weeks retention time of water hyacinth ponds receiving fresh wastewater in Nepal. This difference may be due to the high initial TN concentration $(192.9 \mathrm{mg} / \mathrm{l})$ of the raw wastewater used by these researchers.

Figure 4(f) shows the orthophosphate removal rate in the different ponds as function of time. The orthophosphate showed almost the same trend with time as the TN removal for the different influent $\mathrm{pH}$ values. The optimum removal trend was observed at influent $\mathrm{pH} 7$, while the highest overall cumulative orthophosphate of $1204 \mathrm{mg} / \mathrm{m}^{2}$ was achieved with influent $\mathrm{pH}$ 8. The orthophosphate removal rate seemed not related to $\mathrm{pH}(\mathrm{p}=0.5)$ but to the retention time $(\mathrm{p}=0.001)$, the TN removal $(\mathrm{p}<0.0001)$ rate and the organic load removal rate $(\mathrm{p}<0.03)$.

Table 2. Coliform count in influent and effluent of ponds.

\begin{tabular}{ccccccc}
\hline Pond & Effluent from anaerobic pond & Ponds pH5 & Ponds pH 6 & Ponds pH 7 & Ponds pH 8 & Ponds pH9 \\
\hline Coliforms Number & 15,700 & 46,000 & 19,600 & 1800 & 20,000 & 2500 \\
\hline
\end{tabular}


In general it was observed that organic and nutrients loads removal rates decreased when influent $\mathrm{pH}$ increased from $\mathrm{pH} 7$ to alkaline $\mathrm{pH}$ or decreased from $\mathrm{pH} 7$ to acidic $\mathrm{pH}$.

From the analysis of Table 2, it appears from the coliform count of the effluents of the ponds $\mathrm{pH} 5, \mathrm{pH} 6$ and $\mathrm{pH} 8$ that there was an increase in coliform number in the ponds, despite the long retention time and the presence of WH. In ponds with initial $\mathrm{pH} 7$ and $\mathrm{pH} 9,89 \%$ and $84 \%$ coliform removal was achieved.

It has been reported that coliforms can multiply in treatment facilities or watercourses [31] depending on the environmental conditions. The increase of the coliform number observed can be associated with their multiplication in ponds, which is related to the conditions in the WHP. In fact, after day 3 , the observed $\mathrm{pH}$ in ponds fell within the range of the optimum $\mathrm{pH}$ for faecal bacterial growth which is from 6.5 to 7.5 [20]. Also, the effects of high $\mathrm{pH}$ and sunlight which have been stated to be one of the most beneficial for disinfection in ponds [32] [33] cannot be expected from WHP, as in these ponds acidic conditions prevailed. Furthermore, some works suggest that the addition of nutrients like glucose and saline increase the survival chances of bacteria under both light and dark conditions [34] [35]. This may explain the survival of coliforms and their multiplication in this experiment. The removal observed in ponds with initial $\mathrm{pH} 7$ is due to the very low quantity of solute added to the influent wastewater for $\mathrm{pH}$ spiking. As for the ponds with initial $\mathrm{pH} 9$, the high algae growth and the low WH growth in the ponds may have improved the DO content and the sunlight effect on ponds leading to coliform removal. It would then be wise to provide for a tertiary treatment, in particular the disinfection, after water hyacinth ponds treatment.

\section{4. $\mathrm{pH}$ and Plant Biomass Production}

The water hyacinth relative growth, as measured by biomass fresh weight (FW),

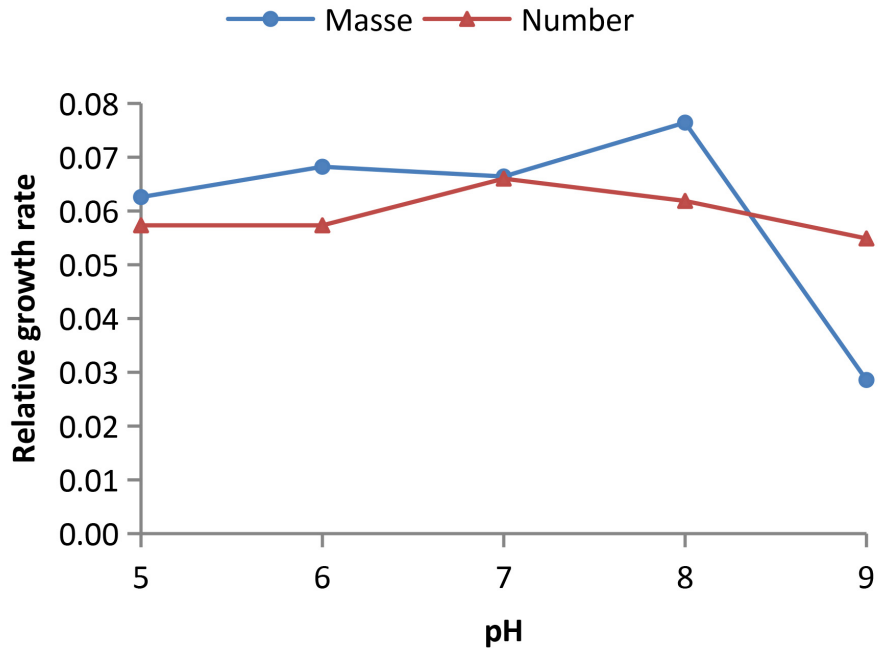

Figure 5. Plant relative growth related to the masse and number of plants as function of influent $\mathrm{pH}$. 
varied between 0.029 and 0.076 with the highest value observed in ponds with $\mathrm{pH}$ 8; but the biggest number of plants was observed in ponds with initial $\mathrm{pH} 7$ (Figure 5). In fact the relative growth rate, as measured by the number of plants, varied between 0.055 and 0.066 with the optimum value observed in ponds with $\mathrm{pH}$ 7. The lowest growth rate was observed in ponds with $\mathrm{pH} 9$.

The mean initial plant unit wet weight was $42.5 \mathrm{~g} \pm 2.6 \mathrm{~g}$. The final unit plant mass varied between $25.6 \mathrm{~g}$ and $56.2 \mathrm{~g}$. The peak values of unit fresh weight were observed in ponds with initial pH 6 and 8 . This can be seen by the higher values of relative growth, as measured by fresh biomass weight and the size of the observed plants in ponds.

\section{Conclusions}

The effect of $\mathrm{pH}$ on the efficiency of water hyacinth ponds (WHP) in treating domestic wastewater and production of plant biomass was carried out in pilot scale ponds under batch flow conditions. The influent domestic wastewater, pretreated anaerobically, was spiked with $\mathrm{H}_{2} \mathrm{SO}_{4}$ or $\mathrm{NaOH}$ to get the desired initial $\mathrm{pH}$ for WHP. Five different influent $\mathrm{pH}(\mathrm{pH} 5, \mathrm{pH} 6, \mathrm{pH} 7, \mathrm{pH} 8$ and $\mathrm{pH} 9)$ were tested. The anaerobic treatment was able to remove $66 \%$ of COD, $56 \%$ of $\mathrm{BOD}_{5}$ and $53 \%$ of TSS after five days retention time.

The observed $\mathrm{pH}$ in WHP for wastewater treatment ranged between 6.4 and 7.1. When the initial $\mathrm{pH}$ values move outside this interval; the plants regulated the $\mathrm{pH}$ of the medium to within this range of 6.4 to 7.1 during the treatment processes. This adjustment affected the performance and the biomass production in the ponds. The alkaline conditions in ponds were less favorable to the activities of the plants.

In fact, removals of $\mathrm{COD}, \mathrm{BOD}_{5}, \mathrm{TNK}$ and growth rates varying respectively, from $18.3 \mathrm{~g} / \mathrm{m}^{2}$ to $33.2 \mathrm{~g} / \mathrm{m}^{2}, 11.5 \mathrm{~g} / \mathrm{m}^{2}$ to $21.0 \mathrm{~g} / \mathrm{m}^{2}, 1.7 \mathrm{~g} / \mathrm{m}^{2}$ to $3.6 \mathrm{~g} / \mathrm{m}^{2}$ and from $0.03 /$ day to $0.07 /$ day were observed after 21 days of treatment, the minimal values being observed in ponds with $\mathrm{pH} 9$ and the maxima corresponding to ponds with initial $\mathrm{pH} 7$.

An influent $\mathrm{pH}$ value around neutral value was then optimum for treatment processes in WHP, meanwhile, the ponds with influent $\mathrm{pH} 6$ and $\mathrm{pH} 8$ showed higher overall total nitrogen and phosphate removal at the end of the experimental period, when the retention time was over fourteen days.

An increase in the faecal coliforms content was observed in the ponds with influent $\mathrm{pH} 5, \mathrm{pH} 6$ and $\mathrm{pH}$ 8; a removal is achieved in ponds with initial $\mathrm{pH} 7$ and $\mathrm{pH}$ 9. These results showed that it is necessary after WHP to provide for effluent disinfection.

Water hyacinth seemed to find its optimum $\mathrm{pH}$ for domestic wastewater treatment and biomass production ranging between 6.4 and 7.1.

\section{Conflicts of Interest}

The authors declare no conflicts of interest regarding the publication of this paper. 


\section{References}

[1] Center, T., Hill, M., Cordo, H. and Julien, M. (2002) Waterhyacinth. In: Van Driesche, R., et al., Eds., Biological Control of Invasive Plants in the Eastern United States, United States Forest Service, Washington DC, 41-64.

[2] Gopal, B. (1987) Water hyacinth. Elsevier Science Publishers, Amsterdam.

[3] Coetzee, J., Hill, M., Julien, M., Center, T. and Cordo, H. (2009) Eichhornia crassipes (Mart.) Solms-Laub. (Pontederiaceae). In: Muniappan, R., Reddy, G.V.P. and Raman, A., Eds., Biological Control of Tropical Weeds using Arthropods, Cambridge University Press, New York, 183-210. https://doi.org/10.1017/CBO9780511576348.011

[4] Malik, A. (2007) Environmental Challenge vis a vis Opportunity: The Case of Water Hyacinth. Environment International, 33, 122-138. https://doi.org/10.1016/j.envint.2006.08.004

[5] Nesic, N. and Jovanovic, L. (2010) Potential Use of Water Hyacinth (E. crassipens) for Wastewater Treatment in Serbia.

[6] Singhal, V. and Rai, J.P.N. (2003) Biogas Production from Water Hyacinth and Channel Grass Used for Phytoremediation of Industrial Effluents. Bioresource Technology, 86, 221-225. https://doi.org/10.1016/s0960-8524(02)00178-5

[7] Wang, Z., Zhang, Z., Zhang, J., Zhang, Y., Liu, H. and Yan, S. (2012) Large-Scale Utilization of Water Hyacinth for Nutrient Removal in Lake Dianchi in China: The Effects on the Water Quality, Macrozoobenthos and Zooplankton. Chemosphere, 89, 1255-1261. https://doi.org/10.1016/j.chemosphere.2012.08.001

[8] Polprasert, C., Kessomboon, S. and Kanjanaprapin, W. (1992) Pig Wastewater Treatment in Water Hyacinth Ponds. Water Science \& Technology, 26, 2381-2384.

[9] Chunkao, K., Nimpee, C. and Duangmal, K. (2012) The King's Initiatives Using Water Hyacinth to Remove Heavy Metals and Plant Nutrients from Wastewater through Bueng Makkasan in Bangkok, Thailand. Ecological Engineering, 39, 40-52. https://doi.org/10.1016/j.ecoleng.2011.09.006

[10] McLay, C. (1976) The Effect of $\mathrm{pH}$ on the Population Growth of Three Species of Duckweed: Spirodela oligorrhiza, Lemna minor and Wolffia arrhiza. Freshwater Biology, 6, 125-136. https://doi.org/10.1111/j.1365-2427.1976.tb01596.x

[11] Bisson, M., Gay, G., Guillard, D., Ghillebaert, F. and Tack, K. (2009) Sélénium et ses composés. I NERIS-Fiche de données toxicologiques et environnementales des substances chimiques.

[12] Pichard, A., Bisson, M., Houeix, N., Gay, G., Lacroix, G., Lefevre, J., Magaud, H., Migne, V., Morin, A. and Tissot, S. (2005) Fiche de données toxicologiques et environnementales des substances chimiques: Cuivre \& ses dérivés. Institut national de l'environnement industriel et des risques, Verneuil-en-Halatte.

[13] Téllez, T.R., López, E., Granado, G.L., Pérez, E.A., López, R.M. and Guzmán, J.M.S. (2008) The Water Hyacinth, Eichhornia crassipes. An Invasive Plant in the Guadiana River Basin (Spain). Aquatic Invasions, 3, 42-53.

[14] Allgayer, R. (2006) Plantes d'aquarium. Editions Artemis, Chamalières.

[15] Azov, Y. and Goldman, J.C. (1982) Free Ammonia Inhibition of Algal Photosynthesis in Intensive Cultures. Applied and Environmental Microbiology, 43, 735-739.

[16] ASCECNA (2008) Données pluviométriques de Cotonou: Station de l'Aéroport de Cotonou. L'Agence pour la Sécurité de la Navigation aérienne en Afrique et à Madagascar, Dakar. 
[17] Hounkpè, S.P., Adjovi, E.C., Crapper, M. and Awuah, E. (2014) Wastewater Management in Third World Cities: Case Study of Cotonou, Benin. Journal of Environmental Protection, 5, 387-399. http://doi.org/10.4236/jep.2014.55042

[18] Soltan, M.E. and Rashed, M.N. (2003) Laboratory Study on the Survival of Water Hyacinth under Several Conditions of Heavy Metal Concentrations. Advances in Environmental Research, 7, 321-334.

[19] Akçin, G., Saltabas, Ö. and Afsar, H. (1994) Removal of Lead by Water Hyacinth (Eichhornia crassipes). Journal of Environmental Science \& Health Part A, 29, 2177-2183. https://doi.org/10.1080/10934529409376172

[20] Awuah, E. (2006) Pathogen Removal Mechanisms in Macrophyte and Algal Waste Stabilization Ponds. Institute for Water Education, Wageningen University and Academic Board of the UNESCO-IHE, Wageningen, 147.

[21] Ashby, E. and Oxley, T. (1935) The Interaction of Factors in the Growth of Lemna VI. An Analysis of the Influence of Light Intensity and Temperature on the Assimilation Rate and the Rate of Frond Multiplication. Annals of Botany, No. 2, 309-336.

[22] Al-Nozaily, F.A. (2001) Performance and Process Analysis of Duckweed-Covered Sewage Lagoons for High Strength Sewage: The Case of Sana'a, Yemen. International Institute for Infrastructural, Hydraulic and Environmental Engineering, Delft University of Technology, Delft, 248.

[23] Hounkpè, S.P., Adjovi, E.C., Crapper, M. and Aïna, M.P. (2013) Mise au point d'un système intégré de gestion des eaux uses. Revue Ivoirienne des Sciences et Technologies, No. 21\&22, 154-173.

[24] Balasooriya, I., Paulraj, P., Abeygunawardena, S. and Nanayakkara, C. (1984) Biology of Water Hyacinth: Physico Chemical Properties of the Water Supporting Eichhornia crassipes (Mart.) Solms. Proceedings of the International Conference on Water Hyacinth, Hyderabad, 7-11 February, 1983.

[25] del Mar Delgado, M., Bigeriego, M., Walter, I. and Guardiola, E. (1994) Optimization of Conditions for the Growth of Water Hyacinth in Biological Treatment. Revista internacional de contaminacion ambiental, 10, 63-68.

[26] Kim, Y. and Kim, W.-J. (2000) Roles of Water Hyacinths and Their Roots for Reducing Algal Concentration in the Effluent from Waste Stabilization Ponds. Water Research, 34, 3285-3294. https://doi.org/10.1016/S0043-1354(00)00068-3

[27] Henze, M., Harremoës, P., la Cour Jansen, J. and Arvin, E. (2001) Wastewater Treatment: Biological and Chemical Processes. Springer, Berlin, Heidelberg.

[28] Pearson, H., Mara, D., Mills, S. and Smallman, D. (1987) Physico-Chemical Parameters Influencing Faecal Bacterial Survival in Waste Stabilization Ponds. Water Science \& Technology, 19, 145-152. https://doi.org/10.2166/wst.1987.0139

[29] Caicedo Bejarano, J.R. (2005) Effect of operational variables on nitrogen transformations in duckweed stabilization ponds. The UNESCO-IHE Institute for Water Education, Delf, 163.

[30] Maharjan, R.B.S. and Ming, C.L. (2012) The Potential Role of Water Hyacinth in Wastewater Treatment in Nepal. Hydro Nepal: Journal of Water, Energy and Environment, 10, 36-41. https://doi.org/10.3126/hn.v10i0.7101

[31] Gibbs, R.A., Hu, C.J., Ho, G.E. and Unkovich, I. (1997) Regrowth of Faecal coliforms and Salmonellae in Stored Biosolids and Soil Amended with Biosolids. Water Science and Technology, 35, 269-275. https://doi.org/10.2166/wst.1997.0745

[32] Gersberg, R.M. and Silvaggio, D.A. (1992) Fate of Coliphage during Wastewater Treatment by Water Hyacinth (Eichhornia crassipes). Ecological Engineering, 1, 355-363. https://doi.org/10.1016/0925-8574(92)90015-t 
[33] Awuah, E., Oppong-Peprah, M., Lubberding, H.J. and Gijzen, H.J. (2004) Comparative Performance Studies of Water Lettuce, Duckweed, and Algal-Based Stabilization Ponds Using Low-Strength Sewage. Journal of Toxicology and Environmental Health, Part A, 67, 1727-1739. https://doi.org/10.1080/15287390490493466

[34] Van der Steen, P., Brenner, A., Shabtai, Y. and Oron, G. (2000) The Effect of Environmental Conditions on Faecal coliform Decay in Post-Treatment of UASB Reactor Effluent. Water Science \& Technology, 42, 111-118.

https://doi.org/10.2166/wst.2000.0621

[35] Liltved, H. and Landfald, B. (2000) Effects of High Intensity Light on UltravioletIrradiated and Non-Irradiated Fish Pathogenic Bacteria. Water Research, 34, 481-486. https://doi.org/10.1016/S0043-1354(99)00159-1 